\title{
Developmental language regression in autism: a descriptive study in Sri Lanka
}

\author{
H Perera ${ }^{1}$, K C Jeewandara ${ }^{2}$, S Seneviratne ${ }^{3}$, B C Guruge ${ }^{2}$ \\ Sri Lanka Journal of Child Health, 2012; 41(1): 15-19
}

(Key words: Developmental regression; autism; prevalence)

\begin{abstract}
Background: Developmental regression is a feature seen in some children with autism and is defined as loss of either language or social skills or both, after a period of apparently normal development.
\end{abstract}

Objective: To estimate the prevalence of developmental language regression (DLR) in a sample of children with autism aged 18-48 months and study the difference with those without DLR in terms of development, social and family variables and outcome of intervention.

Method: Data was obtained from an already existing database of children with autism attending an intervention programme. Information was obtained from the diagnostic assessment, structured parent interview and outcome data on intervention.

Results: Data was available for 62 children. Prevalence of DLR in this group was $41.9 \%$. Mean age of regression was 18 months. More children with DLR compared to those without, were born after assisted conception $(\mathrm{p}<0.05)$. Effect size of outcome of intervention was less favourable for regressed children at 6 months (but not at 3 months).

Conclusion: Prevalence of DLR in this sample of children with autism was $41.9 \%$

\section{Introduction}

Autism is a neuro-developmental disorder where the presenting clinical features can be widely heterogeneous. Developmental language regression

\footnotetext{
${ }^{1}$ Professor, Department of Psychological Medicine, University of Colombo, ${ }^{2}$ Medical Officer in Psychiatry, Lady Ridgeway Hospital for Children, Colombo, ${ }^{3}$ Lecturer Department of Psychological Medicine, University of Colombo
}

(Received on 18 January 2011: Accepted on 25 February 2011)
(DLR) is one such variation. In DLR, children lose previously acquired language skills. The diagnostic tool for autism, the Autism Diagnostic Interview (ADI), defines developmental regression as loss of either language or social skills or both. DLR may determine the timing of diagnosis and is associated with a younger age of identification of autism ${ }^{1}$. Other disorders demonstrating an early regression of skills are congenital blindness, childhood disintegrative disorder, Rett syndrome and Landau-Kleffner syndrome ${ }^{2}$.

Following the controversy regarding the MMR vaccine, which was erroneously blamed for causing autism, developmental regression became a subject of much discussion ${ }^{3}$. Multiple aetiological factors are currently hypothesized to underlie the phenomenon of DLR in autism ${ }^{4}$. DLR in autism shares common pathophysiological features with other regressive disorders but distinct differences are recognized ${ }^{4}$. For example, the mean age of language loss in children with autism is 19.7 months whereas it is 61.8 months in DLR of Down syndrome ${ }^{5}$. While some studies have not found any marked differences in developmental domains between children with autism with and without regression, others have reported significant and persistent problems in terms of receptive and expressive language and play ${ }^{6,7}$. Another related finding was that half of the children with regression had developmental concerns noted prior to the reported loss of skills ${ }^{8}$. In addition, other clinical profiles such as abnormal sleep patterns, epilepsy and frequent epileptiform EEG abnormalities have also been recognised ${ }^{9}$.

\section{Objectives}

The objective of the study was to examine the prevalence of DLR, as reported by the mothers, in a clinical sample of children with autism. More specific objectives were to compare the difference between children with and without DLR in terms of age of presentation, developmental factors, social, family and intervention variables. 


\section{Method}

In this descriptive study DLR was studied in a clinical sample of children, aged 18 to 48 months, attending an early intervention programme for autism. Data was obtained from the already existing database on these children, which was created from information obtained from the diagnostic assessment involving a comprehensive and structured parent interview and observation of the child. Children with DLR were defined as those who were developing normally or near normally in language, where subsequent loss of language was directly reported by mothers or when directly questioned whether their child ñost acquired skills in language, and if so, at what ageò?, answered in the affirmative. Children who did not meet the full criteria for autism including atypical forms were excluded from the study. Children with Rett syndrome, cognitive impairment and where the primary diagnosis was unclear were also excluded.

Outcome of intervention was measured under 5 domains of social / communication namely, sustained eye contact, response to name, social reciprocity, pointing. The measures were taken at the beginning and at 3 and 6 months following commencement of intervention.

Two sets of data were available for comparison. They were of (i) those children who had a positive report for DLR and (ii) those where no such report was available. The comparison was made on multiple demographic, biological, developmental, clinical, social, family and intervention variables. Data was analysed using SPSS version 16 software for cross tabulation and statistical significance.

\section{Results}

A total of 62 children aged 18 to 48 months attended the early intervention programme for autism. Of this sample, 26 children fulfilled criteria for DLR, giving a prevalence of $41.9 \%$ in the sample studied. The mean age of regression as reported by the parents was 18 months (range 12-23 months). All 26 children gave delayed language development and language regression as presenting complaints.

Among the 26 children with DLR, the main presenting complaint was loss of acquired speech in 8 , delay in language development in 12 and use of non-functional words in 1 . In 4 children, the main complaint was disruptive behaviour and aggression. At the time of first assessment, 18 (69.2\%) children with DLR spoke less than 5 words. Similar figure for children without regression was $21(58.3 \%)$. There was no statistically significant difference between the two groups $(p>0.05)$

Table 1 is a comparison between children with and without a history of developmental regression.

Table 1: Comparison between children with and without a history of developmental regression

\begin{tabular}{|c|c|c|c|}
\hline Variable & DLR present $(\mathrm{N}=26)$ & DLR not present $(\mathrm{N}=36)$ & $p$ \\
\hline $\begin{array}{l}\text { Age of presentation } \\
18-24 \text { months } \\
25-36 \text { months } \\
37-48 \text { months }\end{array}$ & $\begin{array}{l}04(15.4 \%) \\
15(57.7 \%) \\
07(26.9 \%) \\
\end{array}$ & $\begin{array}{l}07(19.4 \%) \\
17(47.2 \%) \\
12(33.3 \%) \\
\end{array}$ & 0.542 \\
\hline $\begin{array}{l}\text { Sex: male } \\
\text { female }\end{array}$ & $\begin{array}{l}17(65.4 \%) \\
09(36.6 \%)\end{array}$ & $\begin{array}{l}31(86.1 \%) \\
05(13.9 \%)\end{array}$ & 0.054 \\
\hline $\begin{array}{l}\text { Born after assisted conception } \\
\text { Antenatal problems } \\
\text { Birth complications } \\
\text { Postnatal problems }\end{array}$ & $\begin{array}{c}07(26.9 \%) \\
13(50 \%) \\
14(53.8 \%) \\
02(7.7 \%) \\
\end{array}$ & $\begin{array}{l}02(5.5 \%) \\
07(19.4 \%) \\
21(58.3 \%) \\
04(11.1 \%)\end{array}$ & $\begin{array}{l}0.018 \\
0.104 \\
0.198 \\
0.225\end{array}$ \\
\hline Delay in motor development & $02(7.7 \%)$ & $08(22.2 \%)$ & 0.171 \\
\hline $\begin{array}{l}\text { Stereotyped behaviour } \\
\text { Sensory integration deficits } \\
\text { Medical co morbidities }\end{array}$ & $\begin{array}{c}19(73.07 \%) \\
13(50 \%) \\
4(15.4 \%) \\
\end{array}$ & $\begin{array}{l}21(58.33 \%) \\
15(41.66 \%) \\
12(33.33 \%) \\
\end{array}$ & $\begin{array}{l}0.435 \\
0.373 \\
0.483 \\
\end{array}$ \\
\hline $\begin{aligned} \text { Age of mother }: & <35 \text { years } \\
& 35-40 \text { years } \\
& >40 \text { years } \\
\text { Age of father }: & 35 \text { years } \\
& 35-40 \text { years } \\
> & 40 \text { years }\end{aligned}$ & $\begin{array}{c}15(57.7 \%) \\
08(30.7 \%) \\
03(11.5 \%) \\
5(19.2 \%) \\
15(57.7 \%) \\
6(23.1 \%) \\
\end{array}$ & $\begin{array}{c}25(69.4 \%) \\
11(30.5 \%) \\
00 \\
13(36.1 \%) \\
17(47.2 \%) \\
6(16.7 \%) \\
\end{array}$ & 0.066 \\
\hline $\begin{array}{r}\text { No. of siblings ï none } \\
\text { One } \\
>1\end{array}$ & $\begin{array}{l}18(69.2 \%) \\
05(19.2 \%) \\
03(11.5 \%)\end{array}$ & $\begin{array}{c}21(58.3 \%) \\
13(36.1 \%) \\
02(5.5 \%)\end{array}$ & 0.296 \\
\hline
\end{tabular}


Table 2 is a comparison between children with and without a history of developmental regression with regard to outcome of intervention measured after 3 and 6 months

Table 2: Comparison between children with and without a history of developmental regression with regard to outcome of intervention measured after 3 and 6 months

\begin{tabular}{|c|c|c|c|c|c|c|}
\hline \multirow[t]{2}{*}{$\begin{array}{l}\text { Outcome } \\
\text { measure }\end{array}$} & \multicolumn{2}{|c|}{$\begin{array}{c}\text { Effect size 0-3 months } \\
(95 \% \mathrm{CI})\end{array}$} & \multicolumn{2}{|c|}{$\begin{array}{c}\text { Effect size 0-6 months } \\
(95 \% \mathrm{CI})\end{array}$} & \multicolumn{2}{|c|}{$\begin{array}{c}\text { Effect size 3-6 months } \\
(95 \% \mathrm{CI})\end{array}$} \\
\hline & $\begin{array}{c}\text { Regressed } \\
\text { group }(n=26)\end{array}$ & $\begin{array}{l}\text { Non regressed } \\
\text { group }(n=36)\end{array}$ & $\begin{array}{c}\text { Regressed } \\
\text { group }(n=26)\end{array}$ & $\begin{array}{l}\text { Non regressed } \\
\text { group }(n=36)\end{array}$ & $\begin{array}{c}\text { Regressed } \\
\text { group }(n=26)\end{array}$ & $\begin{array}{l}\text { Non regressed } \\
\text { group }(n=36)\end{array}$ \\
\hline $\begin{array}{l}\text { Sustained eye } \\
\text { contact }\end{array}$ & $\begin{array}{c}1.89 \\
(1.39-2.21)\end{array}$ & $\begin{array}{c}1.54 \\
(1.14-1.94)\end{array}$ & $\begin{array}{c}3.04 \\
(2.94-3.09) \\
\end{array}$ & $\begin{array}{c}2.59 \\
(2.53-2.65)\end{array}$ & $\begin{array}{c}0.79 \\
(0.74-0.84)\end{array}$ & $\begin{array}{c}1.01 \\
(0.95-1.07)\end{array}$ \\
\hline $\begin{array}{l}\text { Response } \\
\text { to name }\end{array}$ & $\begin{array}{c}1.80 \\
(1.41-2.21) \\
\end{array}$ & $\begin{array}{c}1.32 \\
(1.11-1.62) \\
\end{array}$ & $\begin{array}{c}2.8 \\
(2.74-2.86) \\
\end{array}$ & $\begin{array}{c}2.34 \\
(2.28-2.40) \\
\end{array}$ & $\begin{array}{c}0.72 \\
(0.67-0.79) \\
\end{array}$ & $\begin{array}{c}1.02 \\
(0.95-1.09) \\
\end{array}$ \\
\hline $\begin{array}{l}\text { Social } \\
\text { reciprocity }\end{array}$ & $\begin{array}{c}1.79 \\
(1.38-2.18)\end{array}$ & $\begin{array}{c}1.32 \\
(1.02-1.62)\end{array}$ & $\begin{array}{c}2.64 \\
(2.58-2.7)\end{array}$ & $\begin{array}{c}3.01 \\
(2.96-3.06)\end{array}$ & $\begin{array}{c}0.64 \\
(0.58-0.69)\end{array}$ & $\begin{array}{c}1.31 \\
(1.25-1.37)\end{array}$ \\
\hline $\begin{array}{l}\text { Imitative } \\
\text { behaviour }\end{array}$ & $\begin{array}{c}1.81 \\
(1.68-2.06)\end{array}$ & $\begin{array}{c}1.38 \\
(1.18-1.58)\end{array}$ & $\begin{array}{c}2.83 \\
(2.77-2.89)\end{array}$ & $\begin{array}{c}2.95 \\
(2.90-3.00)\end{array}$ & $\begin{array}{c}0.68 \\
(0.63-0.74)\end{array}$ & $\begin{array}{c}1.21 \\
(1.16-1.26)\end{array}$ \\
\hline Pointing & $\begin{array}{c}1.21 \\
(1.17-1.26)\end{array}$ & $\begin{array}{c}1.05 \\
(0.88-1.22)\end{array}$ & $\begin{array}{c}2.03 \\
(1.98-2.08)\end{array}$ & $\begin{array}{c}2.16 \\
(2.10-2.22)\end{array}$ & $\begin{array}{c}0.69 \\
(0.63-0.75)\end{array}$ & $\begin{array}{c}1.14 \\
(1.09-1.19)\end{array}$ \\
\hline
\end{tabular}

\section{Discussion}

The prevalence of DLR in the clinical sample studied was $41.9 \%$. The comparative prevalence found in other studies in autism is $15 \%$ for loss of both language and social skills and $41 \%$ for loss of either language or social skills ${ }^{5}$. Rates as high as $47.3 \%$ and $50 \%$ have been reported in early studies ${ }^{10,11}$, but there is no evidence of a rising prevalence in more recent case series. Population based data has shown a regression rate of 17 to $26 \%$. Under-estimation of the prevalence is thought to occur if language regression alone is taken as a criterion for $\mathrm{DLR}^{4}$. Conversely, majority in our study presented with language regression though a broader definition for regression of either regression in language or social skills or both was used in our study. Broader definition has yielded higher prevalence ${ }^{6}$. On the other hand, over-interpretation of regression is also considered a possibility when children with autism fail to develop social speech as expected ${ }^{12}$.

Mean age of DLR as reported by mothers in the current study was 18 months whereas other studies have found this to be 24 to 27 months $^{8,13}$. However, this did not reflect in the age of presentation. The majority of children in both regressed and nonregressed groups first presented after the age of 2 years. With regard to gender differences in regression, boys were more likely to have documented regression than girls ${ }^{8}$. In contrast, our study found that among girls in the sample, the number presenting with regression was almost 3 times higher than those without (Table 1). In comparison, a higher proportion did not have regression among boys. There was no statistically significant difference between regressed and non- regressed groups with regard to association with comorbid medical disorders, as reported in other studies $^{13-16}$

An interesting finding in our study was a statistically significant association $(\mathrm{p}<0.05)$ between a history of assisted conception for the index pregnancy due to subfertility and DLR (Table 1). A previous report on this finding could not be identified on Medline search, although an association between autism and assisted conception is known ${ }^{17}$. There was no statistically significant difference between autistic children with and without DLR in terms of antenatal and postnatal problems and birth related adverse events. Another association that was evident in our study was the difference in outcome of intervention in the regressed and non-regressed group. In all domains of measurement, the effect size was slightly better in the regressed group at the end of 3 months of intervention. However, at the end of 6 months, the non-regressed group had a larger effect size than the regressed group (Table 2). However, this data is not adequate to predict whether children with autism with regression may do less well than those without regression long term. Nevertheless, it is recognized that autistic children with DLR have a greater level of impairment on global measures of symptomatology, comorbidity, challenging behaviour and social skills $^{12}$.

\section{Shortcomings of the study}

Study relied entirely on retrospective verbal reporting by parents. Videotape analysis of the childôs development or serial clinical records was not available for better validity. Higher percentage estimates of DLR have come from smaller samples or 
samples drawn from clinical referral (Rogers 2004) ${ }^{2}$. The sample in our study falls into the latter category. However, studies using videotape analysis have supported parental claims and shown that they were reliable historians ${ }^{8}$. Yet, the possibility of recall bias cannot be totally ignored.

\section{Conclusions and recommendations}

Prevalence of DLR in this sample of children with autism was $41.9 \%$. Further research based in the community is indicated as the current study cannot be generalized to children with autism in Sri Lanka.

\section{References}

1. Shattuck PT, Durkin M, Maenner M, Newschaffer C, Mandell DS, Wiggins L, et al. Timing of identification among children with autism spectrum disorder: findings from a population-based surveillance study. J Am Acad Child Adolesc Psychiatry 2009; 48: 474-83. http://dx.doi.org/10.1097/CHI.0b013e31819b384 $\underline{8}$

2. Rogers SJ. Developmental regression in autism spectrum disorders. Ment Retard Dev Disabil Res Rev. 2004; 10(2):139-43. http://dx.doi.org/10.1002/mrdd.20027

3. Woo EJ, Ball R, Landa R, Zimmerman AW, Braun MM; VAERS Working Group. Developmental regression and autism reported to the Vaccine Adverse Event Reporting System Autism 2007; 11(4): 301-10.

4. Stefanatos GA. Regression in autistic spectrum disorders. Neuropsychol Rev 2008; 18: 305-19. http://dx.doi.org/10.1007/s11065-008-9073-y

5. Castillo H, Patterson B, Hickey F, Kinsman A, Howard JM, Mitchell T, Molloy CA. Difference in age at regression of children with autism with and without Down syndrome. J Dev Behav Pediatr 2008; 29: 89-93.

http://dx.doi.org/10.1097/DBP.0b013e318165c7 $\underline{8 \mathrm{~d}}$

6. Hansen RL, Ozonoff S, Krakowiak P, Angkustsiri K, Jones C, Deprey LJ, et al. Regression in autism: prevalence and associated factors in the CHARGE study. Ambul Pediatr 2008; 8: 25-31. http://dx.doi.org/10.1016/j.ambp.2007.08.006
7. Bernabei P, Cerquiglini A, Cortesi F, D'Ardia C. Regression versus no regression in the autistic disorder: developmental trajectories. J Autism Dev Disord 2007; 37: 580-8. http://dx.doi.org/10.1007/s10803-006-0201-3

8. Wiggins LD, Rice CE, Baio J. Developmental regression in children with an autism spectrum disorder identified by a population-based surveillance system. Autism 2009; 13: 357-74. http://dx.doi.org/10.1177/1362361309105662

9. Giannotti F, Cortesi F, Cerquiglini A, Miraglia D, Vagnoni C, Sebastiani T, et al. An investigation of sleep characteristics, EEG abnormalities and epilepsy in developmentally regressed and non-regressed children with autism. J Autism Dev Disord 2008; 38: 1888-97 http://dx.doi.org/10.1007/s10803-008-0584-4

10. Davidovitch M, Glick L, Holtzman G, Tirosh E, Safir MP. Developmental regression in autism: maternal perception. J Autism Dev Disord 2000; 30: 113-9. $\underline{\text { http://dx.doi.org/10.1023/A:1005403421141 }}$

11. Chakrabarti S, Fombonne E. Pervasive developmental disorders in preschool children. Journal of the American Medical Association 2001; 285: 3093.

http://dx.doi.org/10.1001/jama.285.24.3093

12. Lingam R, Simmons A, Andrews N, Miller E, Stowe J, Taylor B. Prevalence of autism and parentally reported triggers in a north east London population. Arch Dis Child 2003; 88: 666-70

http://dx.doi.org/10.1136/adc.88.8.666

13. Matson JL, Wilkins J, Fodstad JC. Children with autistic spectrum disorders: a comparison between those who regress vs. those who do not. Dev Neurorehabil 2010; 13: 37-45. http://dx.doi.org/10.3109/17518420903107984

14. Xue Ming, Brimacombe M, Chaaban J, Zimmerman-Bier B, Wagner GC. Autism spectrum disorders: concurrent clinical disorders. J Child Neurol 2008; 23: 6-13. http://dx.doi.org/10.1177/0883073807307102

15. Fong CY, Baird G, Wraige E Do children with autism and developmental regression need EEG investigation in the absence of clinical seizures? Arch Dis Child 2008; 93: 998-9. http://dx.doi.org/10.1136/adc.2008.137273 
16. McVicar KA, Ballaban-Gil K, Rapin I, Moshe SL, Shinnar S. Epileptiform EEG abnormalities in children with language regression. Neurology 2005; 65: 129-31.

http://dx.doi.org/10.1212/01.wnl.0000167193.53 $\underline{817.0 \mathrm{f}}$
17. Hvidtjørn D, Schieve L, Schendel D, Jacobsson B, Sværke C, Thorsen P. Cerebral palsy, autism spectrum disorders and developmental delay in children born after assisted conception: a systematic review and meta-analysis. Arch Pediatr Adolesc Med 2009; 163: 72-83.

http://dx.doi.or/10.1001/archpediatrics.2008.507 